\title{
Cryopreservation of Human Ovarian Tissue: A Review
}

\author{
Ellen Cristina Rivas Leonel ${ }^{a, b} \quad$ Carolina M. Lucci ${ }^{c} \quad$ Christiani A. Amorim ${ }^{a}$ \\ anstitut de Recherche Expérimentale et Clinique, Pôle de Recherche en Gynécologie, Université Catholique de \\ Louvain, Brussels, Belgium; 'bnstitute of Biosciences, Department of Biology, Humanities and Exact Sciences, \\ São Paulo State University, São José do Rio Preto, Brazil; ' Institute of Biological Sciences, Department of Physiology, \\ University of Brasília, Brasília, Brazil
}

\author{
Keywords \\ Ovarian tissue $\cdot$ Fertility preservation · Cancer · Freezing · \\ Vitrification
}

\begin{abstract}
Background: Cryopreservation of human ovarian tissue has been increasingly applied worldwide to safeguard fertility in cancer patients, notably in young girls and women who cannot delay the onset of their treatment. Moreover, it has been proposed to patients with benign pathologies with a risk of premature ovarian insufficiency. So far, more than 130 live births have been reported after transplantation of cryopreserved ovarian tissue, and almost all patients recovered their ovarian function after tissue reimplantation. Summary: This review aims to summarize the recent results described in the literature regarding human ovarian tissue cryopreservation in terms of methods and main results obtained so far. To cryopreserve human ovarian tissue, most studies describe a slow freezing/rapid thawing protocol, which is usually an adaptation of a protocol developed for sheep ovarian tissue. Since freezing has been shown to have a deleterious effect on ovarian stroma and granulosa cells, various research groups have been vitrifying ovarian tissue. Despite promising results, only 2 babies have been born after transplantation of vitrified/warmed ovarian tissue. Optimization of both cryopreservation strategies as well as thawing/warming protocols is therefore necessary to improve the survival of follicles in cryopreserved ovarian tissue. Key Messages: Human ovarian tissue cryopreservation has been successfully applied worldwide to preserve fertility in patients with malignant or nonmalignant pathologies that have a detrimental
\end{abstract}

\section{KARGER}

(๑) 2019 S. Karger AG, Basel effect on fertility. Human ovarian tissue cryopreservation could also be applied as an alternative to postpone pregnancy or menopause in healthy women. Slow freezing and vitrification procedures have been applied to cryopreserve human ovarian tissue, but both alternatives require optimization.

(c) 2019 S. Karger AG, Basel

\section{Introduction}

The International Agency for Research on Cancer estimated that in 2018 more than 276,000 people under 44 years of age were diagnosed with cancer in Europe [1]. The incidence rates are significantly higher among females (65\%) than among males (35\%) in these younger age groups [1]. While current cancer treatment approaches are frequently able to provide disease remission, prolonging patients' life expectancy, they may also lead to infertility as chemoradiotherapy can be very harmful to germ cells [2]. Such fertility loss can be psychologically traumatic for women, as most of them may desire to have biological children. It may affect young individuals as well; thus, the improvement of their quality of life during cytotoxic treatment provides hope in terms of future fertility reestablishment and may be considered an extension of cancer care [3]. Scientific and medical communities have therefore given much attention to fertility preservation - even the National Institute for Clinical Excellence in the UK included this topic as part of the guidance for the management of patients diagnosed with cancer [4]. 
In addition to fertility loss, effects caused by ovarian failure and decreases in ovarian steroidogenesis may lead to increased risks of osteoporosis and heart disease, as well as to menopausal symptoms including hot flushes, libido loss, and hypertension [4]. The usual approach to managing these symptoms is pharmacological hormonal replacement therapies (pHRTs), usually comprising a combination of drugs. While these are highly efficient treatments, in some patients it may be difficult to establish an adequate hormone dosage and delivery. Moreover, the incidence of stroke, venous thromboembolism, heart disease, and cancer may increase due to long-term pHRT administration [5]. As side effects of pHRT may outweigh its benefits, alternative strategies should be proposed to menopausal patients.

In order to restore fertility and endocrine function, ovarian tissue cryopreservation (OTC) can be proposed to these patients, as it allows maintenance of follicular cell viability and helps maintain reproductive capacity as well as ovarian endocrine potential $[6,7]$. This review aims to summarize the recent results described in the literature regarding human OTC.

\section{Indications for OTC}

OTC has a single objective: maintenance of the ovarian structure and physiology, benefiting multiple target patients in different situations. OTC has been indicated mainly to safeguard fertility in cancer patients at risk of ovarian insufficiency and infertility due to gonadotoxic treatments [8]. Moreover, this is the only fertility preservation alternative for prepubertal patients, since in these cases, protocols for ovarian stimulation and oocyte collection are not possible [9]. However, patients with benign conditions such as recurrent ovarian cysts, ovarian torsion, endocrine disorders, and autoimmune diseases may also benefit from this promising technique $[8,10]$.

The OTC technique has enabled the birth of more than 130 healthy babies worldwide [11]. When followed by autotransplantation, success rates are high regarding the reestablishment of ovarian activity $(63.9 \%)$ and natural live births (57.5\%), according to a meta-analysis performed in 2017 [12].

Yet to be mentioned is the growing interest of women in postponing their first pregnancy, owing to education, career planning, or financial instability or even to possible difficulties in finding a partner [13]. The mean age at first pregnancy has increased by 2-4 years in the last 35 years and now is above 30 years [14]. Since both the quality and the amount of follicles decrease considerably with age, cryostorage is an alternative for improving pregnancy outcomes.
OTC can also be indicated for postponing menopause $[15,16]$. The rise in life expectancy in the world population is combining with an increase in the number of menopausal women. In some European countries, most girls born in this century will probably live to be over 100 years old [17], which means that a greater part of their lives will unfold after menopause. Side effects linked to menopause (osteoporosis, cardiovascular problems, sexual dysfunction, depression, etc.) can have a dramatic effect on women's health and quality of life, which has the potential of becoming a significant economic issue. Currently, in the Netherlands, a loss of more than EUR 100 million per year is estimated due to untreated menopausal symptoms [18]. An alternative is the prescription of pHRT. However, pHRT may be unsuitable for some women, including those at increased risk of cardiovascular disease, thromboembolic disease, or some types of cancer. OTC at an early age would safeguard a large population of ovarian follicles that could later be responsible for the production of female hormones, delaying the onset of menopause. In order to avoid the risk of pregnancy and decrease costs associated with ovarian tissue reimplantation, fragments of thawed or warmed ovarian tissue could be heterotopically transplanted.

\section{How to Cryopreserve Human Ovarian Tissue}

\section{Conventional Freezing}

Currently, slow freezing is the most frequently used method for cryopreserving human ovarian tissue. This procedure uses programmable freezers to achieve controlled freezing rates. In any slow freezing process, ice crystals form first outside the cells/tissue. As water solidifies, the outside milieu becomes hypertonic. As has long been known, fast cooling rates prevent intracellular water from leaving the cells, resulting in ice crystal formation inside the cells and consequent cell damage. On the other hand, slow cooling rates allow osmotic adjustments between intra- and extracellular fluid, but they may lead to excessive dehydration and shrinkage [19-21].

The addition of cryoprotectant agents (CPAs) to the cryopreservation medium helps to overcome these problems. The role of CPAs is to protect the cells against injuries caused by both ice crystals and hypertonicity during cryopreservation. However, CPAs can have osmotic effects upon the cells during freezing/thawing procedures. When cells are exposed to permeating CPAs, they initially undergo dehydration and shrinkage followed by a return to the original volume as the CPA enters the cell. These changes in volume can cause cell damage or even death, depending on their rapidity and magnitude. Addition of CPAs can cause cell damage also by chemical toxicity [22]. Optimal exposure should aim to minimize osmotic stress while avoiding chemical toxicity and allow 
Table 1. Slow freezing methods used by the most prominent groups performing fertility preservation worldwide

\begin{tabular}{|c|c|c|c|c|c|}
\hline Country & $\begin{array}{l}\text { Base medium and } \\
\text { supplements }\end{array}$ & CPAs & Equilibrium & Cooling curve & Ref. \\
\hline Belgium & $\begin{array}{l}\text { Minimum essential medium }(\mathrm{MEM})+ \\
4 \mathrm{mg} / \mathrm{mL} \text { HSA }\end{array}$ & $10 \%$ DMSO & $30 \mathrm{~min}$ at $0^{\circ} \mathrm{C}$ & $\begin{array}{l}-2^{\circ} \mathrm{C} / \mathrm{min} \text { to }-8^{\circ} \mathrm{C} \text {, manual seeding, }-0.3^{\circ} \mathrm{C} / \mathrm{min} \text { to }-40^{\circ} \mathrm{C} \text {, and }-30^{\circ} \mathrm{C} / \mathrm{min} \\
\text { to }-140^{\circ} \mathrm{C}\end{array}$ & 67 \\
\hline Belgium & Leibovitz L-15 medium & $\begin{array}{l}1.5 \mathrm{M} \text { DMSO } \\
0.1 \mathrm{M} \text { sucrose }\end{array}$ & $30 \mathrm{~min}$ at $4^{\circ} \mathrm{C}$ & $\begin{array}{l}-2^{\circ} \mathrm{C} / \mathrm{min} \text { to }-7^{\circ} \mathrm{C} \text {, manual seeding, }-0.3^{\circ} \mathrm{C} / \mathrm{min} \text { to }-40^{\circ} \mathrm{C} \text {, and }-10^{\circ} \mathrm{C} / \mathrm{min} \\
\text { to }-140^{\circ} \mathrm{C}\end{array}$ & 68-71 \\
\hline Denmark & PBS & $\begin{array}{l}1.5 \mathrm{M} \text { EG } \\
0.1 \mathrm{M} \text { sucrose }\end{array}$ & $30 \mathrm{~min}$ at $1^{\circ} \mathrm{C}$ & $\begin{array}{l}2^{\circ} \mathrm{C} / \mathrm{min} \text { to }-9^{\circ} \mathrm{C} \text {, manual seeding, }-0.3^{\circ} \mathrm{C} / \mathrm{min} \text { to }-40^{\circ} \mathrm{C} \text {, and }-10^{\circ} \mathrm{C} / \mathrm{min} \\
\text { to }-140^{\circ} \mathrm{C}\end{array}$ & $72-75$ \\
\hline Portugal & $\begin{array}{l}\text { RPMI } 1640 \text { medium + GlutaMAX and } \\
15 \% \text { FCS }\end{array}$ & $10 \%$ DMSO & $30 \mathrm{~min}$ at $4^{\circ} \mathrm{C}$ & Overnight in a freezer at $-80^{\circ} \mathrm{C}$ & 76 \\
\hline Australia & PBS + albumin & $\begin{array}{l}1.5 \mathrm{~mol} \text { PROH } \\
0.1 \mathrm{M} \text { sucrose }\end{array}$ & $\begin{array}{l}30 \text { min at room } \\
\text { temperature }\end{array}$ & $\begin{array}{l}-2^{\circ} \mathrm{C} / \mathrm{min} \text { to }-8^{\circ} \mathrm{C} \text {, manual seeding, }-0.3^{\circ} \mathrm{C} / \mathrm{min} \text { to }-30^{\circ} \mathrm{C} \text {, and }-50^{\circ} \mathrm{C} / \mathrm{min} \\
\text { to }-150^{\circ} \mathrm{C}\end{array}$ & $77-79$ \\
\hline Australia & Dulbecco's PBS & $\begin{array}{l}1.5 \mathrm{M} \text { DMSO } \\
0.1 \mathrm{M} \text { Sucrose }\end{array}$ & & & 80 \\
\hline France & $\begin{array}{l}\text { Leibovitz L-15 medium }+10 \% \\
\text { decomplemented patient serum }\end{array}$ & $\begin{array}{l}1.5 \mathrm{M} \text { DMSO } \\
0.1 \mathrm{M} \text { sucrose }\end{array}$ & & & 81 \\
\hline France & Leibovitz L-15 medium + 10\% FCS & $1.5 \mathrm{M}$ DMSO & On ice for $15 \mathrm{~min}$ & $-2^{\circ} \mathrm{C} / \mathrm{min}$ to $-7^{\circ} \mathrm{C}$, seeding, $-0.3^{\circ} \mathrm{C} / \mathrm{min}$ to $-40^{\circ} \mathrm{C}$, and $-10^{\circ} \mathrm{C} / \mathrm{min}$ to $-140^{\circ} \mathrm{C}$ & 82 \\
\hline Germany & PBS & $\begin{array}{l}1.5 \mathrm{M} \mathrm{DMSO}+ \\
1.5 \mathrm{M} \mathrm{PROH}\end{array}$ & $\begin{array}{l}\text { Increasing steps of } 0.25 \mathrm{M} \\
\text { up to } 1.25 \mathrm{M} \text { of } \mathrm{DMSO} / \mathrm{PROH} \\
(7 \mathrm{~min} \text { each) and then } 1.5 \mathrm{M} \\
\text { DMSO/PROH }(30 \mathrm{~min}) \text { at } 37^{\circ} \mathrm{C}\end{array}$ & $\begin{array}{l}-5^{\circ} \mathrm{C} / \min \text { to }-3.8^{\circ} \mathrm{C},-1^{\circ} \mathrm{C} / \min \text { to }-5.3^{\circ} \mathrm{C},-0.2^{\circ} \mathrm{C} / \min \text { to }-6^{\circ} \mathrm{C} \text {, hold } \\
\text { for } 20 \mathrm{~min}\left(\text { autocrystallization), }-0.3^{\circ} \mathrm{C} / \min \text { to }-30^{\circ} \mathrm{C},-0.1^{\circ} \mathrm{C} / \mathrm{min} \text { to }-35^{\circ} \mathrm{C} \text {, }\right. \\
-0.3^{\circ} \mathrm{C} / \mathrm{min} \text { to }-80^{\circ} \mathrm{C} \text {, and }-10^{\circ} \mathrm{C} / \mathrm{min} \text { to }-110^{\circ} \mathrm{C}\end{array}$ & 83 \\
\hline Germany & $\begin{array}{l}\text { Leibovitz L-15 GlutaMAX medium + } \\
\text { serum substitute supplement }\end{array}$ & $10 \%$ DMSO & $30 \mathrm{~min}$ at $2^{\circ} \mathrm{C}$ & $\begin{array}{l}-2^{\circ} \mathrm{C} / \mathrm{min} \text { to }-6^{\circ} \mathrm{C} \text {, automatic seeding, }-0.3^{\circ} \mathrm{C} / \mathrm{min} \text { to }-40^{\circ} \mathrm{C},-10^{\circ} \mathrm{C} / \mathrm{min} \\
\text { to }-140^{\circ} \mathrm{C} \text {, stored at }-150^{\circ} \mathrm{C} \text { in MVE Vapor phase storage tanks }\end{array}$ & 26 \\
\hline Spain & RPMI $1640+20 \%$ human serum & $1.5 \mathrm{M}$ DMSO & $\begin{array}{l}10 \mathrm{~min} \text { at } 4^{\circ} \mathrm{C} \text { in } 0.7 \mathrm{M} \mathrm{DMSO} \text { and } \\
10 \mathrm{~min} \text { at } 4^{\circ} \mathrm{C} \text { in } 1.5 \mathrm{M} \mathrm{DMSO}\end{array}$ & $\begin{array}{l}-0.5^{\circ} \mathrm{C} / \mathrm{min} \text { to }-7^{\circ} \mathrm{C} \text {, automatic seeding, }-0.5^{\circ} \mathrm{C} / \mathrm{min} \text { to }-50^{\circ} \mathrm{C},-5^{\circ} \mathrm{C} / \mathrm{min} \\
\text { to }-80^{\circ} \mathrm{C} \text {, and }-8^{\circ} \mathrm{C} / \mathrm{min} \text { to }-120^{\circ} \mathrm{C}\end{array}$ & 84,85 \\
\hline Spain & M199 + 5\% human serum & $12.5 \%$ DMSO & Not mentioned & $\begin{array}{l}-1.5^{\circ} \mathrm{C} / \mathrm{min} \text { to }-12^{\circ} \mathrm{C} \text {, seeding, }-10^{\circ} \mathrm{C} / \mathrm{min} \text { to }-30^{\circ} \mathrm{C},-5^{\circ} \mathrm{C} / \mathrm{min} \text { to }-20^{\circ} \mathrm{C} \text {, } \\
\text { stabilization at }-20^{\circ} \mathrm{C} \text { for } 5 \mathrm{~min},-0.5^{\circ} \mathrm{C} / \mathrm{min} \text { to }-50^{\circ} \mathrm{C},-5^{\circ} \mathrm{C} / \mathrm{min} \text { to }-80^{\circ} \mathrm{C} \text {, } \\
\text { and }-8^{\circ} \mathrm{C} / \mathrm{min} \text { to }-120^{\circ} \mathrm{C}\end{array}$ & 86 \\
\hline Sweden & PBS & $\begin{array}{l}1.5 \mathrm{M} \text { PROH } \\
0.1 \mathrm{M} \text { sucrose }\end{array}$ & $\begin{array}{l}\text { Room temperature } \\
\text { (time not mentioned) }\end{array}$ & $\begin{array}{l}\text { Using the programmable freezing device CTE } 920 \text { with automatic seeding at } \\
\text { an optimal temperature (detailed curve not described) }\end{array}$ & 87 \\
\hline Sweden & Leibovitz L- 15 medium + 10\% FCS & 1.5 M DMSO & On ice for $15 \mathrm{~min}$ & $-2^{\circ} \mathrm{C} / \mathrm{min}$ to $-7^{\circ} \mathrm{C}$, seeding, $-0.3^{\circ} \mathrm{C} / \mathrm{min}$ to $-40^{\circ} \mathrm{C}$, and $-10^{\circ} \mathrm{C} / \mathrm{min}$ to $-140^{\circ} \mathrm{C}$ & 88 \\
\hline Israel & $\begin{array}{l}\text { Oocyte wash buffer }+15 \% \text { synthetic } \\
\text { serum }\end{array}$ & $\begin{array}{l}1.5 \mathrm{M} \text { DMSO } \\
0.1 \mathrm{M} \text { sucrose }\end{array}$ & $30 \mathrm{~min}$ & $\begin{array}{l}-1^{\circ} \mathrm{C} / \mathrm{min} \text { to }-9^{\circ} \mathrm{C} \text {, manual seeding, }-0.3^{\circ} \mathrm{C} / \mathrm{min} \text { to }-36^{\circ} \mathrm{C} \text {, and }-5^{\circ} \mathrm{C} / \mathrm{min} \\
\text { to }-140^{\circ} \mathrm{C}\end{array}$ & 89,90 \\
\hline Israel & Leibovitz L-15 medium $+10 \%$ HSA & $\begin{array}{l}1.5 \mathrm{M} \text { DMSO } \\
0.1 \mathrm{M} \text { sucrose }\end{array}$ & $30 \mathrm{~min}$ at $4^{\circ} \mathrm{C}$ & $\begin{array}{l}-2^{\circ} \mathrm{C} / \mathrm{min} \text { to }-9^{\circ} \mathrm{C} \text {, manual seeding, }-0.3^{\circ} \mathrm{C} / \mathrm{min} \text { to }-40^{\circ} \mathrm{C} \text {, and }-10^{\circ} \mathrm{C} / \mathrm{min} \\
\text { to }-140^{\circ} \mathrm{C}\end{array}$ & 91 \\
\hline USA & $\begin{array}{l}\text { HEPES-buffered Dulbecco's minimum } \\
\text { essential medium (DMEM)-F12 }\end{array}$ & $\begin{array}{l}1.5 \mathrm{M} \text { DMSO } \\
0.1 \mathrm{M} \text { sucrose }\end{array}$ & $30 \mathrm{~min}$ on ice & $\begin{array}{l}-2^{\circ} \mathrm{C} / \mathrm{min} \text { to }-7^{\circ} \mathrm{C} \text {, manual seeding, }-0.3^{\circ} \mathrm{C} / \mathrm{min} \text { to }-40^{\circ} \mathrm{C} \text {, and }-10^{\circ} \mathrm{C} / \mathrm{min} \\
\text { to }-140^{\circ} \mathrm{C}\end{array}$ & 92 \\
\hline USA & Leibovitz L-15 medium + 10\% FCS & $1.5 \mathrm{M}$ DMSO & On ice for $15 \mathrm{~min}$ & $-2^{\circ} \mathrm{C} / \mathrm{min}$ to $-7^{\circ} \mathrm{C}$, seeding, $-0.3^{\circ} \mathrm{C} / \mathrm{min}$ to $-40^{\circ} \mathrm{C}$, and $-10^{\circ} \mathrm{C} / \mathrm{min}$ to $-140^{\circ} \mathrm{C}$ & 93 \\
\hline UK & Leibovitz & $\begin{array}{l}1.5 \mathrm{M} \text { DMSO } \\
2.5 \% \mathrm{HSA}\end{array}$ & $30 \mathrm{~min}$ at $4^{\circ} \mathrm{C}$ & $\begin{array}{l}-2^{\circ} \mathrm{C} / \mathrm{min} \text { to }-9^{\circ} \mathrm{C} \text {, manual seeding, }-0.3^{\circ} \mathrm{C} / \mathrm{min} \text { to }-40^{\circ} \mathrm{C} \text {, and }-10^{\circ} \mathrm{C} / \mathrm{min} \\
\text { to }-140^{\circ} \mathrm{C}\end{array}$ & 94 \\
\hline UK & Leibovitz L-15 medium + 10\% FCS & $1.5 \mathrm{M}$ DMSO & On ice for $15 \mathrm{~min}$ & $-2^{\circ} \mathrm{C} / \mathrm{min}$ to $-7^{\circ} \mathrm{C}$, seeding, $-0.3^{\circ} \mathrm{C} / \mathrm{min}$ to $-40^{\circ} \mathrm{C}$, and $-10^{\circ} \mathrm{C} / \mathrm{min}$ to $-140^{\circ} \mathrm{C}$ & 95 \\
\hline
\end{tabular}

CPAs, cryoprotectant agents; DMSO, dimethyl sulfoxide; EG, ethylene glycol; FCS, fetal calf serum; HSA, human serum albumin; PBS, phosphate-buffered saline; PROH, 1,2-propanediol.

sufficient permeation and dehydration to achieve protection from freezing injuries.

CPAs are divided into two categories [23]:

- Permeating agents: glycerol, dimethyl sulfoxide (DMSO), ethylene glycol, and 1,2-propanediol $(\mathrm{PROH})$; these have a low molecular weight and can pass through the lipid bilayer of the cell membrane, although they do so more slowly than water

- Nonpermeating agents: sugars (sucrose, trehalose, and raffinose) and macromolecules (Ficoll and polyvinylpyrrolidone), as well as proteins and lipoproteins; these remain in the extracellular solution, for they are large molecules, and help to promote controlled cell dehydration
In most slow freezing protocols for ovarian tissue, a combination of one permeating agent and one nonpermeating agent is used. CPA concentrations are around $1.5 \mathrm{M}$ for the permeating agent (usually DMSO) and 0.1 $\mathrm{M}$ for the nonpermeating agent (usually sucrose). Details on the protocols used by the leading groups working with OTC worldwide are presented in Table 1. Particular care should be taken regarding the permeation of CPAs in ovarian samples, as different types of cell and extracellular matrix compose the tissue. For instance, a higher equilibration period should be proposed for allowing the CPAs to perfuse to the inner tissue areas. Also for this purpose, ovarian tissue biopsies are cut into thin strips. 


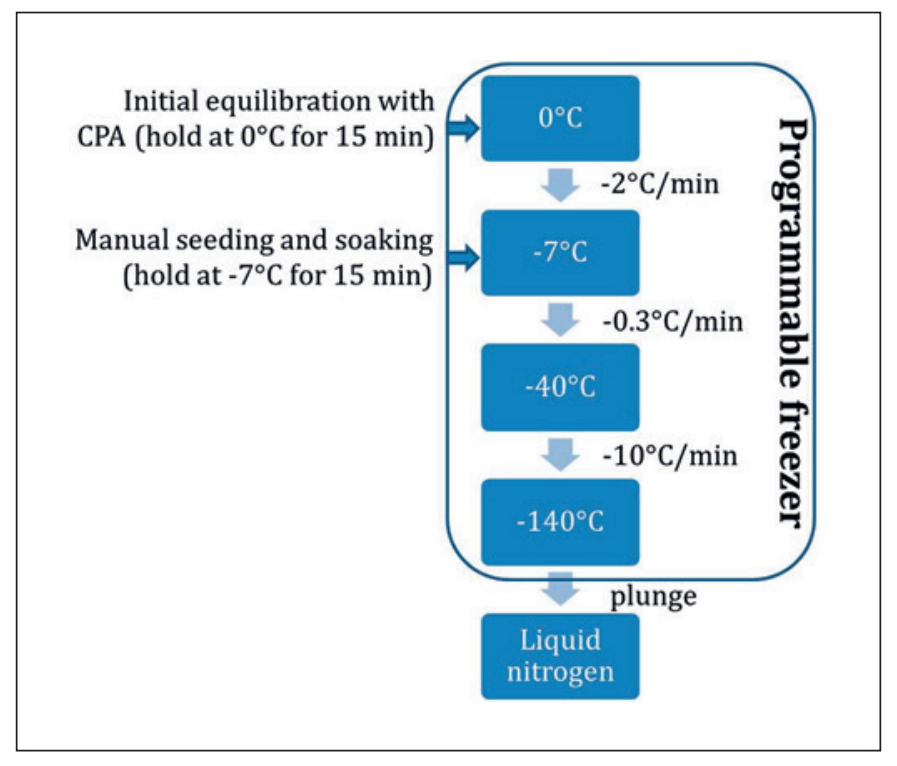

Fig. 1. Cooling curve in slow freezing protocols for human ovarian tissue.

Although many studies have highlighted the importance of establishing optimal conditions for the use of each cryoprotectant in complex multicellular systems, few differences in protocols have been observed between groups (Table 1). Indeed, slow freezing protocols for human ovarian tissue are based on the protocol described by Gosden et al. [24], which follows a sequence of steps (Fig. 1) with slight variations, such as changes regarding the time and/or temperature of equilibrium with CPAs and the seeding temperature (Table 1).

Gook et al. [25] tested a two-step method for CPA permeation, consisting of $10 \mathrm{~min}$ in $1.5 \mathrm{~mol} \mathrm{PROH}$ and then $30 \mathrm{~min}$ in $1.5 \mathrm{~mol} \mathrm{PROH}+0.1 \mathrm{~mol}$ sucrose, versus onestep methods, with both CPAs together, for 30,60 , or 90 min. The authors concluded that single-step dehydration for 90 min allowed the highest proportion of intact and morphologically preserved primordial follicles.

In some countries, national programs with centralized cryobanks have been created, so that only a few centers with proven expertise perform cryopreservation of ovarian tissue that fulfills certain quality criteria. An example is FertiPROTEKT, a network of fertility preservation programs in Germany, Switzerland, and Austria [26].

\section{Vitrification}

More recently, human ovarian tissue has also been cryopreserved by means of vitrification. So far, only 2 live births have been reported after cryopreserving human ovarian tissue using this procedure $[27,28]$.

Vitrification is a process of converting a supercooled liquid into a glass-like amorphous solid, preventing ice crystal formation [22]. Vitrification processes are based on an ultrafast cooling rate combined with a high concentration of CPAs [29]. However, high concentrations of CPAs have toxic effects on the cells [22]. Because of this, vitrification methods usually use a combination of two or more CPAs [30-33], so that the sum of their concentrations supports vitrification, while the low concentration of each CPA reduces their toxic effects [34]. In theory, any permeating CPA may be used for vitrification. However, ethylene glycol is being established as the best choice [30], because of its low toxicity and rapid diffusion into cells [35].

Another factor that influences vitrification is the volume of the sample. The smaller the sample, the less liquid is required to be cooled, and the lower the probability of ice crystal formation [29]. To achieve low volumes of liquid, different approaches are used, such as medium droplets [30, 32], a solid surface [35], a silver closed vitrification system [33], and plastic straws [36].

Cryopreservation by vitrification is attractive because it is a quick and easy procedure and does not require special and expensive equipment. Although it seems simple to perform, if cooling rates are not fast enough, crystallization may occur. In a successful vitrification, the tissue and surrounding solution become transparent, whereas failed vitrification is characterized by an opaque white sample, meaning ice crystals have formed $[28,29]$.

Despite the growing popularity of this type of preservation, it is still rarely used for ovarian tissue preservation. Unlike the slow freezing procedure, there is no standard vitrification protocol for ovarian tissue. Apart from the 2 babies reported by the Japanese group [27, 28], promising results using vitrified ovarian tissue were also reported by Kiseleva et al. [37]. In their case study, vitrified ovarian tissue showed recovery of its reproductive potential after autotransplantation [37].

\section{Thawing/Warming and the Risk of Recrystallization}

The risk of ice formation during warming is an important factor to be taken into account with slowly frozen or vitrified tissue. Cooling and warming rates interact, and a suitable outcome can be found when both are carefully taken into consideration.

Devitrification is the process of conversion of ultraviscous water into crystalline ice. Recrystallization happens when small ice crystals formed during temperature reduction grow while warming; as a result there is an opaque appearance in a previously clear sample [38]. The risk of recrystallization is greater for vitrified systems [39], as the warming process plays an even greater role than the cooling rate [40]. Water should turn from liquid directly to glass in vitrification. However, during warming, there is a possibility of ice crystal formation rather than "devitri- 
Table 2. Examples of thawing/warming protocols described in the literature

\begin{tabular}{|c|c|c|c|}
\hline $\begin{array}{l}\text { Cryopreservation } \\
\text { method }\end{array}$ & $\begin{array}{l}\text { Final CPA } \\
\text { concentration }\end{array}$ & Thawing/warming method & Ref. \\
\hline SF & $1.5 \mathrm{M} \mathrm{EG}$ & $\begin{array}{l}\text { 10-min water bath at } 37^{\circ} \mathrm{C} ; 10 \text {-min baths with lower EG concentrations, sucrose, } \\
\text { and PBS at RT }\end{array}$ & 96 \\
\hline Vitrification & $35 \% \mathrm{EG}$ & TCM199, SSS, and sucrose at $37^{\circ} \mathrm{C}$; 3 -min bath with TCM199, SSS, and sucrose at RT & 28 \\
\hline SF & 1.5 M DMSO & 2 min in air at RT; water bath at RT; 3 baths in Leibovitz L-15 medium & 24 \\
\hline SF & 1.5 м DMSO & $\begin{array}{l}30 \mathrm{~s} \text { in air at RT; } 2 \text {-min water bath at } 37^{\circ} \mathrm{C} \text {; } 5 \text {-min baths with lower DMSO } \\
\text { concentrations and sucrose }\end{array}$ & 90 \\
\hline
\end{tabular}

CPA, cryoprotectant agent; SF, slow freezing; EG, ethylene glycol; DMSO, dimethyl sulfoxide; PBS, phosphate-buffered saline; RT, room temperature; SSS, serum substitute supplement.

fication" by the conversion of glass into a highly viscous supercooled liquid [40]. The warming procedure of vitrified systems occurs in three phases [38]: (1) conversion of the solution from vitrified into ultraviscous, (2) devitrification (conversion of water into crystalline ice), and (3) recrystallization (growth of very small ice crystals) [41]. The formation of small ice nuclei during vitrification is inevitable. However, when sufficient time is available during warming, more nucleation and crystal growth can occur, leading to morphological damage to the tissue [42]. To avoid this, it is essential to increase the warming rate and ensure an adequate CPA concentration.

Once the sample is warmed/thawed, attention should be directed at CPA removal. During this step, an osmotic imbalance may occur due to water uptake suffered by the cells, causing their swelling. This is even worse in vitrified tissue, where higher concentrations of CPAs are present in the tissue fragments. To avoid or minimize this problem, CPA removal can be slowly performed. For this, solutes like proteins (human serum albumin or serum substitute supplement) or sugars (glucose or sucrose) can be used, controlling CPA removal. Usually, a mixture of solutions containing lower CPA concentrations is applied during CPA removal. An overview of some protocols described for human ovarian tissue thawing/warming is shown in Table 2.

\section{Future Trends in OTC}

Despite the successful results obtained after transplantation of cryopreserved ovarian tissue, studies have shown that freezing negatively affects the ovarian stromal tissue [43-48], granulosa cells $[25,48,49]$, and theca cell formation [50], which may be involved in the significant number of empty follicles observed in women with grafted frozen-thawed ovarian tissue [50] and the limited life span of the graft [51]. These findings could be due to ice crystal formation, an inherent step in the freezing procedure and the major source of injury and cell death. In order to optimize a freezing protocol for human ovarian tissue, and to achieve a more homogeneous CPA distribution inside the ovarian tissue samples, Corral et al. [52] decided to modify various parameters in the current slow freezing procedures (Fig. 1). They demonstrated that better CPA permeation and homogeneity in bovine ovarian tissue was observed with a higher DMSO concentration $(20 \%)$ and lower seeding temperature $\left(-11^{\circ} \mathrm{C}\right)$ [52]. This protocol was then tested on human ovarian tissue, and while ice formation was less likely to occur in the samples frozen with a $20 \%$ DMSO concentration due to the higher CPA content inside the tissue fragments, it did not improve follicle survival after short-term xenografting (Fig. 2) [53]. Nevertheless, a longer period of xenotransplantation could eventually show a possible benefit from this optimized protocol.

A few years ago, directional freezing was tested to cryopreserve ovarian tissue [54]. This strategy allows for a precise and uniform cooling rate in samples of different sizes, through a thermodynamic principle where ice crystals are controlled throughout the sample by regulating the sample movement rate through the predetermined temperature gradient [55]. In this way, the tissue sample is cooling while ice crystals are growing in the opposite direction of the sample movement. This procedure successfully allowed the cryopreservation of whole sheep ovaries [54]. Despite these promising findings, directional freezing has not yet been tested on human ovarian tissue.

As previously mentioned, vitrification has been considered an alternative to slow freezing, as it has been shown to preserve the ultrastructure of stromal tissue [47, 56]. However, vitrification is based on three crucial steps: addition of high CPA concentrations and achievement of high cooling and warming rates to decrease CPA toxicity. To avoid the toxic CPA effects, Corral et al. [57] devel- 


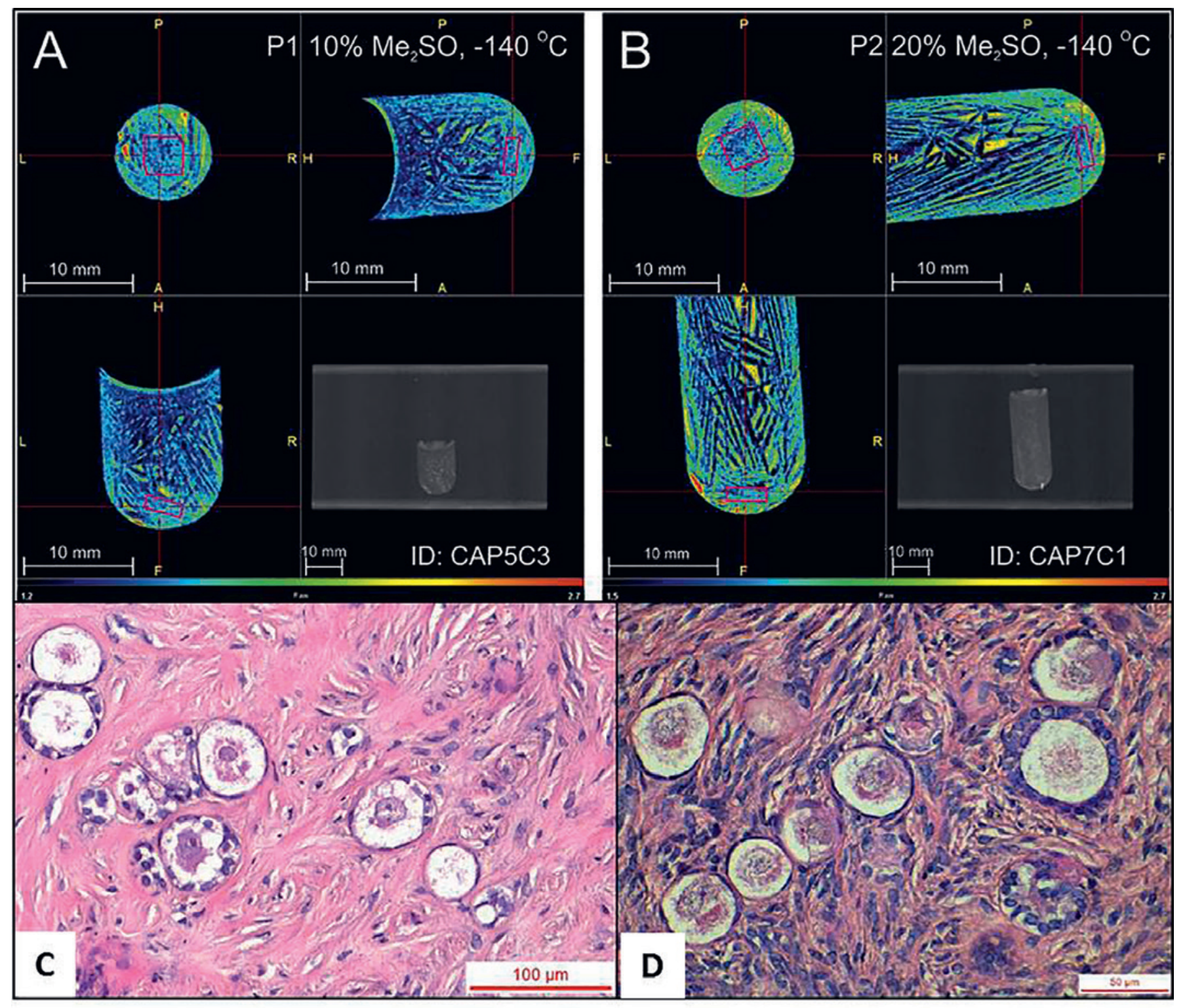

Fig. 2. A, B Computed tomography images of ovarian tissue samples inside cryovials at $-140^{\circ} \mathrm{C}$. The spatial resolution is $0.1 \mathrm{~mm}$, and the color scale ranges from dark blue for low attenuation (1.2 $\mathrm{CT})$ to intense red for high attenuation $(3.0 \mathrm{CT})$. The pink cube is a volume of interest measuring $3 \times 3 \times 1 \mathrm{~mm}$ located within the tissue. C Tissue sample cryopreserved with $10 \%$ DMSO. The ice structure is shown in dark blue, surrounded by small islands of high DMSO concentration. The tissue cannot be distinguished from the solution around it, although the presence of ice is less pronounced in the sample area. D Tissue sample cryopreserved with $20 \%$ DMSO. The ice structure is shown in dark blue and the tissue area is green in color corresponding to a higher DMSO concentration than seen in $10 \%$ DMSO (C). Xenografted primordial and primary follicles from human ovarian tissue cryopreserved with $10 \%($ C) and $20 \%$ DMSO (D). Reproduced with permission from Elsevier ${ }^{\circledR}[53]$. oped a procedure called "stepped vitrification," which consists of gradually decreasing the temperature while $\mathrm{CPA}$ is increased. The difference between their strategy and equilibrium vitrification is that the decline in CPA toxicity with temperature and reduction in the system melting point do not need to follow the same curve [57]. Corral et al. [57] tested their new procedure to vitrify bovine ovarian tissue by increasing the DMSO concentration in increments while simultaneously decreasing the temperature in increments, using a device specifically designed for this purpose. Their promising findings revealed follicles with histological integrity after warming similar to fresh controls [57].

Another important concern regarding vitrification is that fast cooling and warming rates are technically difficult to control, especially with bulky samples due to the constraints of heat transfer. Indeed, when the tissue fragment is immersed in liquid nitrogen, the temperature difference induces the formation of gas bubbles around the sample, which shields it from direct contact with the 
liquid nitrogen, negatively affecting the cooling rate. This phenomenon, called the Leidenfrost effect [58], can be avoided by using slush nitrogen, which can increase the cooling rate and decrease CPA concentration and exposure [59]. Recently, Barbato et al. [59] and Talevi et al. [60] tested an ultrarapid vitrification procedure using slush nitrogen to cryopreserve human ovarian tissue and reported an improvement in follicle ultrastructure, viability, and development, as well as preservation of stromal cell integrity.

New approaches have also been developed for improving thawing/warming of cryopreserved tissue. Manuchehrabadi et al. [61] tested a nanowarming technique to warm tissue samples. This idea was raised as an alternative in order to reduce failure during the warming process performed on large samples. Nanoparticles can be suspended in vitrification or freezing solution and used to induce a uniform heat increase in cryopreserved samples. This strategy relies on the concept of nanoparticle oscillations promoted by the laser wave, which produce heat dissipation throughout the sample, allowing for uniform warmth [62]. Iron [63] as well as gold [64] nanoparticles have been cited for this purpose. To induce particle stimulation, radio frequency and light may be used. However, aggregation with proteins or other solutes may occur [65], reducing the heat generation capacity of these systems. These effects can be reduced by coating the particles with silica or polypropylene glycol [66]. A possible concern with nanowarming is the risk of causing toxic effects to the tissue. However, low toxicity was observed after warming vitrified porcine carotid arteries and zebrafish embryos, using iron oxide and gold, respectively $[61,63]$. Since large fragments of organs can be successfully warmed using nanowarming, this could potentially be applied to human ovarian tissue as well.

\section{Conclusion}

OTC has been increasingly applied to preserve fertility of cancer patients and women with benign conditions and, more recently, has been discussed as a strategy for postponing pregnancy and menopause in healthy women. While more robust results have been reported for slow freezing procedures, various centers worldwide have started to test vitrification protocols. Nevertheless, optimization of both cryopreservation strategies and thawing/warming protocols is necessary to improve the survival of follicles in cryopreserved ovarian tissue.

\section{Statement of Ethics}

The authors have no ethical conflicts to disclose.

\section{Disclosure Statement}

The authors have no conflicts of interest to declare.

\section{Funding Sources}

The authors would like to acknowledge the financial support from Fundação de Amparo à Pesquisa do Estado de São Paulo (FAPESP) for grant 2016/22947-8 to E.C. Rivas Leonel. C.A. Amorim is a research associate of the FRS-FNRS.

\section{Author Contributions}

All authors contributed to the conception and writing of this review article.

\section{References}

1 International Agency for Research on Cancer [Internet]. Lyon: Cancer today; 2018 [cited 2018 Dec 7]. Available from: https://gco.iarc.fr/ today/online-analysis-table $\mathrm{v}=2018 \& \operatorname{mode}=$ cancer\&mode_population $=$ continents\&popul ation $=900 \&$ populations $=900 \& \mathrm{key}=$ asr $\& \operatorname{sex}=0$ \& cancer $=39 \&$ type $=0$ \&statistic $=5 \&$ prevalence $=0 \&$ population_group $=0 \&$ ages_group $\%$ $5 \mathrm{~B} \% 5 \mathrm{D}=0$ \&ages_group $\% 5 \mathrm{~B} \% 5 \mathrm{D}=17 \& \mathrm{nb}$ items $=5 \&$ group_cancer $=1 \&$ include_ nmsc $=1$ \&include_nmsc_other $=1$.T

2 Vassilakopoulou M, Boostandoost E, Papaxoinis G, de La Motte Rouge T, Khayat D, Psyrri A. Anticancer treatment and fertility: effect of therapeutic modalities on reproductive system and functions. Crit Rev Oncol Hematol. 2016 Jan;97:328-34.

3 Turan V, Oktay K. Sexual and fertility adverse effects associated with chemotherapy treatment in women. Expert Opin Drug Saf. 2014 Jun;13(6):775-83.
4 National Institute for Clinical Excellence [Internet]. Fertility problems: assessment and treatment [cited 2018 Dec 7]. London: National Institute for Clinical Excellence; 2013 [updated 2017]. Available from: https://www. nice.org.uk/guidance/cg 156 ? unlid= 1019425172201622615722.

5 Marjoribanks J, Farquhar CM, Roberts H, Lethaby A. Cochrane corner: long-term hormone therapy for perimenopausal and postmenopausal women. Heart. 2018 Jan;104(2):93-5.

6 Donnez J, Dolmans MM. Transplantation of ovarian tissue. Best Pract Res Clin Obstet Gynaecol. 2014 Nov;28(8):1188-97.

7 Dolmans MM. Recent advances in fertility preservation and counseling for female cancer patients. Expert Rev Anticancer Ther. 2018 Feb;18(2):115-20.

8 Gellert SE, Pors SE, Kristensen SG, Bay-Bjørn AM, Ernst E, Yding Andersen C. Transplantation of frozen-thawed ovarian tissue: an up- date on worldwide activity published in peerreviewed papers and on the Danish cohort. J Assist Reprod Genet. 2018 Apr;35(4):561-70.

9 Donnez J, Dolmans MM. Fertility preservation in women. N Engl J Med. 2018 Jan; 378(4):400-1.

10 Donnez J. Fertility preservation in women, focusing on cancer, benign diseases and social reasons. Minerva Ginecol. 2018 Aug;70(4):385-6.

11 Donnez J, Dolmans MM. Fertility preservation in women. N Engl J Med. 2017 Oct; 377(17):1657-65.

12 Pacheco F, Oktay K. Current success and efficiency of autologous ovarian transplantation: a meta-analysis. Reprod Sci. 2017 Aug; 24(8):1111-20.

13 Hammarberg K, Clarke VE. Reasons for delaying childbearing - a survey of women aged over 35 years seeking assisted reproductive technology. Aust Fam Physician. 2005 Mar; 34(3):187-8. 
14 Organisation for Economic Co-operation and Development [Internet]. OECD Family Database: Age of mothers at childbirth and age-specific fertility [cited 2018 Dec 7]. Paris: OECD. Available from: http://www.oecd.org/ els/family/database.htm.

15 Amorim CA, Gonçalves PB, Figueiredo JR. Cryopreservation of oocytes from pre-antral follicles. Hum Reprod Update. 2003 MarApr;9(2):119-29.

16 Amorim CA, Rivas Leonel EC, Afifi A, Coomarasamy A, Fishel S. Cryostorage and retransplantation of ovarian tissue as an infertility treatment. Best Pract Res Clin Endocrinol Metab. 2018. [Epub ahead of print]

17 Christensen K, Doblhammer G, Rau R, Vaupel JW. Ageing populations: the challenges ahead. Lancet. 2009 Oct;374(9696):1196-208.

18 Reuters [Internet]. USA: untreated hot flashes may be costly for society: study [cited 2018 Dec 7]. Available from: https://www.reuters. com/article/us-women-health-menopauseproductivity-idUSKBN0H320G20140908.

19 Mazur P. Kinetics of water loss from cells at subzero temperatures and the likelihood of intracellular freezing. J Gen Physiol. 1963 Nov;47(2):347-69.

20 Mazur P. Freezing of living cells: mechanisms and implications. Am J Physiol. 1984 Sep; 247(3 Pt 1):C125-42.

21 Mazur P, Leibo SP, Chu EH. A two-factor hypothesis of freezing injury. Evidence from Chinese hamster tissue-culture cells. Exp Cell Res. 1972;71(2):345-55.

22 Fahy GM, MacFarlane DR, Angell CA, Meryman HT. Vitrification as an approach to cryopreservation. Cryobiology. 1984 Aug;21(4): 407-26.

23 Amorim CA, Curaba M, Van Langendonckt A, Dolmans MM, Donnez J. Vitrification as an alternative means of cryopreserving ovarian tissue. Reprod Biomed Online. 2011 Aug; 23(2):160-86.

24 Gosden RG, Baird DT, Wade JC, Webb R. Restoration of fertility to oophorectomized sheep by ovarian autografts stored at $-196 \mathrm{de}$ grees C. Hum Reprod. 1994 Apr;9(4):597603.

25 Gook DA, Edgar DH, Stern C. Effect of cooling rate and dehydration regimen on the histological appearance of human ovarian cortex following cryopreservation in 1,2-propanediol. Hum Reprod. 1999 Aug;14(8):2061-8.

26 Van der Ven H, Liebenthron J, Beckmann M, Toth B, Korell M, Krüssel J, et al.; FertiPROTEKT network. Ninety-five orthotopic transplantations in 74 women of ovarian tissue after cytotoxic treatment in a fertility preservation network: tissue activity, pregnancy and delivery rates. Hum Reprod. 2016 Sep;31(9): 2031-41.

27 Kawamura K, Cheng Y, Suzuki N, Deguchi M, Sato Y, Takae S, et al. Hippo signaling disruption and Akt stimulation of ovarian follicles for infertility treatment. Proc Natl Acad Sci USA. 2013 Oct;110(43):17474-9.

28 Suzuki N, Yoshioka N, Takae S, Sugishita Y, Tamura M, Hashimoto S, et al. Successful fertility preservation following ovarian tissue vitrification in patients with primary ovarian insufficiency. Hum Reprod. 2015 Mar;30(3) 608-15.
29 Yavin S, Arav A. Measurement of essential physical properties of vitrification solutions. Theriogenology. 2007 Jan;67(1):81-9.

30 Amorim CA, David A, Van Langendonckt A, Dolmans MM, Donnez J. Vitrification of human ovarian tissue: effect of different solutions and procedures. Fertil Steril. 2011 Mar; 95(3):1094-7.

31 Kagawa N, Kuwayama M, Nakata K, Vajta G, Silber S, Manabe N, et al. Production of the first offspring from oocytes derived from fresh and cryopreserved pre-antral follicles of adult mice. Reprod Biomed Online. 2007 Jun; 14(6):693-9.

32 Li YB, Zhou CQ, Yang GF, Wang Q, Dong Y. Modified vitrification method for cryopreservation of human ovarian tissues. Chin Med J (Engl). 2007 Jan;120(2):110-4.

33 Xiao Z, Zhang Y, Fan W. Cryopreservation of human ovarian tissue using the silver closed vitrification system. J Assist Reprod Genet. 2017 Nov;34(11):1435-44.

34 Wusteman M, Robinson M, Pegg D. Vitrification of large tissues with dielectric warming: biological problems and some approaches to their solution. Cryobiology. 2004 Apr;48(2): 179-89.

35 Huang L, Mo Y, Wang W, Li Y, Zhang Q, Yang D. Cryopreservation of human ovarian tissue by solid-surface vitrification. Eur J Obstet Gynecol Reprod Biol. 2008 Aug;139(2):193-8.

36 Gandolfi F, Paffoni A, Papasso Brambilla E, Bonetti S, Brevini TA, Ragni G. Efficiency of equilibrium cooling and vitrification procedures for the cryopreservation of ovarian tissue: comparative analysis between human and animal models. Fertil Steril. 2006 Apr;85 Suppl 1:1150-6.

37 Kiseleva M, Malinova I, Komarova E, Shvedova T, Chudakov K. The Russian experience of autotransplantation of vitrified ovarian tissue to a cancer patient. Gynecol Endocrinol. 2014 Oct;30(Suppl 1):30-1.

38 Seki S, Mazur P. Effect of warming rate on the survival of vitrified mouse oocytes and on the recrystallization of intracellular ice. Biol Reprod. 2008 Oct;79(4):727-37.

39 Lv F, Liu B, Li W, Jaganathan GK. Devitrification and recrystallization of nanoparticlecontaining glycerol and PEG-600 solutions. Cryobiology. 2014 Feb;68(1):84-90.

40 Seki S, Mazur P. The dominance of warming rate over cooling rate in the survival of mouse oocytes subjected to a vitrification procedure. Cryobiology. 2009 Aug;59(1):75-82.

41 Mishima O, Stanley HE. The relationship between liquid, supercooled, and glassy water. Nature. 1998 Nov;396(6709):329-35.

42 Rall WF. Factors affecting the survival of mouse embryos cryopreserved by vitrification. Cryobiology. 1987 Oct;24(5):387-402.

43 Schubert B, Canis M, Darcha C, Artonne C, Smitz J, Grizard G. Follicular growth and estradiol follow-up after subcutaneous xenografting of fresh and cryopreserved human ovarian tissue. Fertil Steril. 2008 Jun;89(6): 1787-94.

44 Nottola SA, Camboni A, Van Langendonckt A, Demylle D, Macchiarelli G, Dolmans MM, et al. Cryopreservation and xenotransplantation of human ovarian tissue: an ultrastructural study. Fertil Steril. 2008 Jul;90(1):23-32.
45 Fabbri R, Pasquinelli G, Bracone G, Orrico C, Di Tommaso B, Venturoli S. Cryopreservation of human ovarian tissue. Cell Tissue Bank. 2006;7(2):123-33

46 Camboni A, Martinez-Madrid B, Dolmans MM, Nottola S, Van Langendonckt A, Donnez J. Autotransplantation of frozen-thawed ovarian tissue in a young woman: ultrastructure and viability of grafted tissue. Fertil Steril. 2008 Oct;90(4):1215-8.

47 Keros V, Xella S, Hultenby K, Pettersson K, Sheikhi M, Volpe A, et al. Vitrification versus controlled-rate freezing in cryopreservation of human ovarian tissue. Hum Reprod. 2009 Jul;24(7):1670-83.

48 Siebzehnrübl E, Kohl J, Dittrich R, Wildt L. Freezing of human ovarian tissue - not the oocytes but the granulosa is the problem. Mol Cell Endocrinol. 2000 Nov;169(1-2):109-11.

49 Eyden B, Radford J, Shalet SM, Thomas N, Brison DR, Lieberman BA. Ultrastructural preservation of ovarian cortical tissue cryopreserved in dimethylsulfoxide for subsequent transplantation into young female cancer patients. Ultrastruct Pathol. 2004 Jul-Aug; 28(4):239-45.

50 Amorim CA, David A, Dolmans MM, Camboni A, Donnez J, Van Langendonckt A. Impact of freezing and thawing of human ovarian tissue on follicular growth after long-term xenotransplantation. J Assist Reprod Genet. 2011 Dec;28(12):1157-65.

51 Donnez J, Silber S, Andersen CY, Demeestere I, Piver P, Meirow D, et al. Children born after autotransplantation of cryopreserved ovarian tissue. a review of 13 live births. Ann Med. 2011;43(6):437-50.

52 Corral A, Balcerzyk M, Gallardo M, Amorim CA, Parrado-Gallego Á, Risco R. An optimized controlled rate slow cooling protocol for bovine ovarian tissue cryopreservation by means of X-ray computed tomography. Theriogenology. 2018 Oct;119:183-8.

53 Gallardo M, Paulini F, Corral A, Balcerzyk M, Lucci CM, Ambroise J, et al. Evaluation of a new freezing protocol containing $20 \%$ dimethyl sulphoxide concentration to cryopreserve human ovarian tissue. Reprod Biomed Online. 2018 Dec;37(6):653-65.

54 Maffei S, Pennarossa G, Brevini TA, Arav A, Gandolfi F. Beneficial effect of directional freezing on in vitro viability of cryopreserved sheep whole ovaries and ovarian cortical slices. Hum Reprod. 2014 Jan;29(1):114-24.

55 Arav A, Natan D. Directional freezing of reproductive cells and organs. Reprod Domest Anim. 2012 Aug;47 Suppl 4:193-6.

56 Wang Y, Xiao Z, Li L, Fan W, Li SW. Novel needle immersed vitrification: a practical and convenient method with potential advantages in mouse and human ovarian tissue cryopreservation. Hum Reprod. 2008 Oct;23(10):2256-65.

57 Corral A, Clavero M, Gallardo M, Balcerzyk M, Amorim CA, Parrado-Gallego Á, et al. Ovarian tissue cryopreservation by stepped vitrification and monitored by X-ray computed tomography. Cryobiology. 2018 Apr;81:17-26.

58 Song YS, Adler D, Xu F, Kayaalp E, Nureddin A, Anchan RM, et al. Vitrification and levitation of a liquid droplet on liquid nitrogen. Proc Natl Acad Sci USA. 2010 Mar;107(10): 4596-600. 
59 Barbato V, Gualtieri R, Capriglione T, Pallotta MM, Braun S, Di Nardo M, et al. Slush nitrogen vitrification of human ovarian tissue does not alter gene expression and improves follicle health and progression in long-term in vitro culture. Fertil Steril. 2018 Dec;110(7): 1356-66.

60 Talevi R, Barbato V, Fiorentino I, Braun S, De Stefano C, Ferraro R, et al. Successful slush nitrogen vitrification of human ovarian tissue. Fertil Steril. 2016 Jun;105(6):1523-31.e1.

61 Manuchehrabadi N, Gao Z, Zhang J, Ring HL, Shao Q, Liu F, et al. Improved tissue cryopreservation using inductive heating of magnetic nanoparticles. Sci Transl Med. 2017 Mar;9(379):eaah4586.

62 Jaque D, Martínez Maestro L, del Rosal B, Haro-Gonzalez P, Benayas A, Plaza JL, et al. Nanoparticles for photothermal therapies. Nanoscale. 2014 Aug;6(16):9494-530.

63 Khosla K, Wang Y, Hagedorn M, Qin Z, Bischof J. Gold nanorod induced warming of embryos from the cryogenic state enhances viability. ACS Nano. 2017 Aug;11(8):786978 .

64 Jeon S, Hurley KR, Bischof JC, Haynes CL, Hogan CJ. Quantifying intra- and extracellular aggregation of iron oxide nanoparticles and its influence on specific absorption rate. Nanoscale. 2016 Sep;8(35):16053-64.

65 Hurley KR, Ring HL, Etheridge M, Zhang J, Gao Z, Shao Q, et al. Predictable heating and positive MRI contrast from a mesoporous silica-coated iron oxide nanoparticle. $\mathrm{Mol}$ Pharm. 2016 Jul;13(7):2172-83.

66 Brockbank KG, Chen Z, Greene ED, Campbell LH. Vitrification of heart valve tissues. Methods Mol Biol. 2015;1257:399-421.

67 Donnez J, Dolmans MM, Demylle D, Jadoul P, Pirard C, Squifflet J, et al. Livebirth after orthotopic transplantation of cryopreserved ovarian tissue. Lancet. 2004 Oct;364(9443): 1405-10.

68 Demeestere I, Simon P, Dedeken L, Moffa F, Tsépélidis S, Brachet C, et al. Live birth after autograft of ovarian tissue cryopreserved during childhood. Hum Reprod. 2015 Sep;30(9): 2107-9.

69 Demeestere I, Simon P, Buxant F, Robin V, Fernandez SA, Centner J, et al. Ovarian function and spontaneous pregnancy after combined heterotopic and orthotopic cryopreserved ovarian tissue transplantation in a patient previously treated with bone marrow transplantation: case report. Hum Reprod. 2006 Aug;21(8):2010-4.

70 Demeestere I, Simon P, Emiliani S, Delbaere A, Englert Y. Fertility preservation: successful transplantation of cryopreserved ovarian tissue in a young patient previously treated for Hodgkin's disease. Oncologist. 2007 Dec; 12(12):1437-42.

71 Demeestere I, Simon P, Moffa F, Delbaere A, Englert Y. Birth of a second healthy girl more than 3 years after cryopreserved ovarian graft. Hum Reprod. 2010 Jun;25(6):1590-1.

72 Jensen AK, Kristensen SG, Macklon KT, Jeppesen JV, Fedder J, Ernst E, et al. Out- comes of transplantations of cryopreserved ovarian tissue to 41 women in Denmark. Hum Reprod. 2015 Dec;30(12):2838-45.

73 Rosendahl M, Loft A, Byskov AG, Ziebe S, Schmidt KT, Andersen AN, et al. Biochemical pregnancy after fertilization of an oocyte aspirated from a heterotopic autotransplant of cryopreserved ovarian tissue: case report. Hum Reprod. 2006 Aug;21(8):2006-9.

74 Macklon KT, Jensen AK, Loft A, Ernst E, Andersen CY. Treatment history and outcome of 24 deliveries worldwide after autotransplantation of cryopreserved ovarian tissue, including two new Danish deliveries years after autotransplantation. J Assist Reprod Genet. 2014 Nov;31(11):1557-64

75 Ernst E, Bergholdt S, Jørgensen JS, Andersen CY. The first woman to give birth to two children following transplantation of frozen/ thawed ovarian tissue. Hum Reprod. 2010 May;25(5):1280-1.

76 Póvoa A, Xavier P, Calejo L, Soares S, Sousa M, Silva J, et al. First transplantation of cryopreserved ovarian tissue in Portugal, stored for 10 years: an unexpected indication. Reprod Biomed Online. 2016 Mar;32(3):334-

77 Stern CJ, Gook D, Hale LG, Agresta F, Oldham J, Rozen G, et al. Delivery of twins following heterotopic grafting of frozen-thawed ovarian tissue. Hum Reprod. 2014 Aug;29(8): 1828.

78 Stern CJ, Gook D, Hale LG, Agresta F, Oldham J, Rozen G, et al. First reported clinical pregnancy following heterotopic grafting of cryopreserved ovarian tissue in a woman after a bilateral oophorectomy. Hum Reprod. 2013 Nov;28(11):2996-9.

79 Stern CJ, Toledo MG, Hale LG, Gook DA, Edgar $\mathrm{DH}$. The first Australian experience of heterotopic grafting of cryopreserved ovarian tissue: evidence of establishment of normal ovarian function. Aust N Z J Obstet Gynaecol. 2011 Jun;51(3):268-75.

80 Burmeister L, Kovacs GT, Osianlis T. First Australian pregnancy after ovarian tissue cryopreservation and subsequent autotransplantation. Med J Aust. 2013 Feb;198(3):1589.

81 Roux C, Amiot C, Agnani G, Aubard Y, Rohrlich PS, Piver P. Live birth after ovarian tissue autograft in a patient with sickle cell disease treated by allogeneic bone marrow transplantation. Fertil Steril. 2010 May;93(7): 2413.e15-9.

82 Poirot C, Abirached F, Prades M, Coussieu C, Bernaudin F, Piver P. Induction of puberty by autograft of cryopreserved ovarian tissue. Lancet. 2012 Feb;379(9815):588.

83 Dittrich R, Mueller A, Binder H, Oppelt PG, Renner SP, Goecke T, et al. First retransplantation of cryopreserved ovarian tissue following cancer therapy in Germany. Dtsch Arztebl Int. 2008 Apr;105(15):274-8.

84 Callejo J, Salvador C, González-Nuñez S, Almeida L, Rodriguez L, Marqués L, et al. Live birth in a woman without ovaries after autograft of frozen-thawed ovarian tissue com- bined with growth factors. J Ovarian Res. 2013 May;6(1):33.

85 Callejo J, Salvador C, Miralles A, Vilaseca S, Lailla JM, Balasch J. Long-term ovarian function evaluation after autografting by implantation with fresh and frozen-thawed human ovarian tissue. J Clin Endocrinol Metab. 2001 Sep;86(9):4489-94.

86 Sánchez M, Novella-Maestre E, Teruel J, Ortiz E, Pellicer A, Mirabet V. The Valencia Programme for fertility preservation. Clin Transl Oncol. 2008 Jul;10(7):433-8.

87 Wølner-Hanssen P, Hägglund L, Ploman F, Ramirez A, Manthorpe R, Thuring A. Autotransplantation of cryopreserved ovarian tissue to the right forearm $4(1 / 2)$ years after autologous stem cell transplantation. Acta Obstet Gynecol Scand. 2005 Jul;84(7):695-8.

88 Milenkovic M, Brännström M, Diaz-Garcia C, Lundin K, Selleskog U, Söderlund B, et al. Spontaneous twin pregnancy with live births after cryopreservation and re-implantation of ovarian tissue. Gynecol Surg. 2017;14(1):9.

89 Shapira M, Raanani H, Barshack I, Amariglio N, Derech-Haim S, Marciano MN, et al. First delivery in a leukemia survivor after transplantation of cryopreserved ovarian tissue, evaluated for leukemia cells contamination. Fertil Steril. 2018 Jan;109(1):48-53.

90 Meirow D, Levron J, Eldar-Geva T, Hardan I, Fridman E, Yemini Z, et al. Monitoring the ovaries after autotransplantation of cryopreserved ovarian tissue: endocrine studies, in vitro fertilization cycles, and live birth. Fertil Steril. 2007 Feb;87(2):418.e7-15.

91 Revel A, Laufer N, Ben Meir A, Lebovich M, Mitrani E. Micro-organ ovarian transplantation enables pregnancy: a case report. Hum Reprod. 2011 May;26(5):1097-103.

92 Oktay K, Oktem O. Ovarian cryopreservation and transplantation for fertility preservation for medical indications: report of an ongoing experience. Fertil Steril. 2010 Feb;93(3):7628.

93 Silber S, Pineda J, Lenahan K, DeRosa M, Melnick J. Fresh and cryopreserved ovary transplantation and resting follicle recruitment. Reprod Biomed Online. 2015 Jun;30(6):64350.

94 Radford JA, Lieberman BA, Brison DR, Smith AR, Critchlow JD, Russell SA, et al. Orthotopic reimplantation of cryopreserved ovarian cortical strips after high-dose chemotherapy for Hodgkin's lymphoma. Lancet. 2001 Apr;357(9263):1172-5.

95 Dunlop CE, Brady BM, McLaughlin M, Telfer EE, White J, Cowie F, et al. Re-implantation of cryopreserved ovarian cortex resulting in restoration of ovarian function, natural conception and successful pregnancy after haematopoietic stem cell transplantation for Wilms tumour. J Assist Reprod Genet. 2016 Dec;33(12):1615-20.

96 Rosendahl M, Schmidt KT, Ernst E, Rasmussen PE, Loft A, Byskov AG, et al. Cryopreservation of ovarian tissue for a decade in Denmark: a view of the technique. Reprod Biomed Online. 2011 Feb;22(2):162-71. 